University of South Florida

DIGITAL COMMONS

Digital Commons @ University of

@ UNIVERSITY OF SOUTH FLORIDA

South Florida

USF Accountability Reports

USF Archives

$1-1-2010$

\title{
2010 Work Plan USF Tampa
}

USF

Follow this and additional works at: https://digitalcommons.usf.edu/usf_accountability_reports

\section{Scholar Commons Citation}

USF, "2010 Work Plan USF Tampa" (2010). USF Accountability Reports. 15.

https://digitalcommons.usf.edu/usf_accountability_reports/15

This Article is brought to you for free and open access by the USF Archives at Digital Commons @ University of South Florida. It has been accepted for inclusion in USF Accountability Reports by an authorized administrator of Digital Commons @ University of South Florida. For more information, please contact digitalcommons@usf.edu. 


\section{University Work Plan / Proposal}

\section{University of South Florida - Tampa}

\section{Strategic Plan}

The 2007-2012 USF Tampa Strategic Plan is a bold, ambitious plan to elevate the performance and rankings of the University of South Florida as one of the nation's leading research universities. It provides the USF community with a clear vision, goals, strategies, and measures to promote alignment and success. It is clearly directed at ensuring student success, contributing innovation and new knowledge, and advancing economic development in Florida, the nation, and globally.

http://www.ods.usf.edu/Plans/Strategic/

\section{Mission Statement}

As Florida's leading metropolitan research university, USF Tampa is dedicated to excellence in:

- Student access and success in an engaged, and interdisciplinary, learner-centered environment,

- Research and scientific discovery, including the generation, dissemination, and translation of new knowledge across disciplines; to strengthen the economy; to promote civic culture and the arts; and to design and build sustainable, healthy communities, and

- Embracing innovation, and supporting scholarly and artistic engagement to build a community of learners together with significant and sustainable university-community partnerships and collaborations.

http://www.ods.usf.edu/Plans/Strategic/vision-mission.htm 


\section{Overview of Core Institutional Strengths, Special Assets, and Niche Contributions}

\section{GOAL 1: ACCESS TO AND PRODUCTION OF DEGREES}

USF Tampa is committed to access and the success of its students. Production of degrees is a culmination of student experiences, achievements, and success at the institution, and therefore becomes a measure of student success. As such, student success (i.e. enhanced preparedness, retention, persistence, graduation and placement rates) has been the primary goal of undergraduate and graduate education initiatives.

In 2008-09, USF Tampa awarded 8,730 degrees, of which more than 6,000 were bachelor's degrees, more than 2,000 were master's degrees, and nearly 300 were doctoral degrees. At the undergraduate level, the university has made significant investments in programs and services to help students meet their fullest potential. By increasing the number of academic advisors, expanding tutoring services, encouraging undergraduate research, improving orientation, constructing new residence halls, and updating policies, USF Tampa is taking a comprehensive approach to improving the undergraduate experience in an effort to improve graduation rates and the overall collegiate experience.

In support of the university's strategic plan, graduate enrollment and diversity are on the rise - an indication of USF Tampa's intentions to strengthen its position as Florida's number two research university. Graduate studies and research are the hallmarks of the Tampa campus as a premier destination for world-class graduate students, postdoctoral fellows and faculty. Graduate and professional education at USF Tampa has been on a strong forward trajectory with exemplary educational and research opportunities for graduate students developed to promote our next state, national, and global leaders.

Graduate level I hours (master's courses) have increased 3-4\% and Graduate level II (doctoral graduate hours) have increased $23 \%$. Diversity numbers are also strong, rising to $23 \%$ of all graduate students. The USF Tampa Graduate School is outperforming institutional goals for number of doctorates awarded, particularly in STEM areas, international student enrollment, and time to degree completion. Continuing this trend prepares the nation's next generation of leaders, thinkers and scientists by replenishing the ranks of the professoriate for American higher education.

USF Tampa's student diversity is a hallmark of the institution and has been recognized by leading publications over the past several years. Overall, more than one third of the USF Tampa student body is comprised of students who identify themselves as races/ethnicities that are non-White.

USF Tampa is located less than 10 minutes from downtown, where the institution also maintains a center for professional and workforce education. USF Health's presence permeates the Tampa Bay area through partnerships with hospitals and other health care organizations throughout Hillsborough County. The institution's broad geographic reach further supports its commitment to providing access to higher education.

\section{GOAL 2: MEETING STATEWIDE PROFESSIONAL AND WORKFORCE NEEDS}

As a leading research university, USF Tampa offers a broad array of undergraduate and graduate degree programs preparing students to become leaders in business, industry, service, and research. Many degree programs align with state goals to meet professional and workforce needs, including education, health professions, the sciences, and emerging technologies. Following the guidelines and selection of areas of strategic emphasis identified by the Board of Governors staff in consultation with business and industry groups, USF Tampa has experienced a positive growth trend in all identified areas (i.e., Education, Health Professions, STEM areas, Security \& Emergency Services, Globalization, and Regional Workforce Needs). From 2004 to 2008, USF Tampa has had a $45 \%$ increase in total degrees awarded combined for all areas of strategic emphasis. 


\section{GOAL 3: BUILDING WORLD-CLASS ACADEMIC PROGRAMS AND RESEARCH CAPACITY}

Research is a centerpiece of the university's strategic plan, is fundamental to the recruitment and retention of top faculty and gives a university distinction. Consistent with the USF Tampa Strategic Plan, the university has four internationally recognized research themes which span the entire campus: sustainability, integrated neurosciences, diabetes, and drug design, development and delivery.

Research is also the hallmark of every college, department and program at USF Tampa. It is an expectation and a privilege of every faculty member, whether it is sponsored by an external funding or carried out with support of university resources. As a result, there are scores of projects investigating basic research problems and tackling applied societal challenges that together all enhance our understanding of the world in the creation of new knowledge.

USF Tampa's research enterprise is also remarkable on the national level. In fiscal year 2007, USF Tampa ranked $61^{\text {st }}$ of total research and development expenditures (external funding) for all universities and colleges and $40^{\text {th }}$ of all public institutions. USF Tampa also ranks 38th in federal research expenditures for public universities and 62nd for all universities (TARU, 2009, Annual Report). Last year, USF Tampa's funded research generated around \$380 million in external awards from federal, state, industry, foundation and other sponsors who are our partners in discovery and innovation that benefits Florida citizens, develops and commercializes products, knowhow and processes, and creates start-up companies and jobs. Such activities lead to economic development and create solutions to local, national and global problems.

Research firmly connects the university with the local Tampa Bay community through service, outreach and engagement activities, the corporate community through patenting and licensing of technology and targeted research, with other academics through collaborative and cooperative programs and globally through our relationships with research colleagues. Research also connects the system through multidisciplinary approaches to a common problem. Research provides opportunity to students and prepares them for success in their chosen fields or for graduate and professional education.

Of equal importance, research and scholarship in the humanities and arts improve the quality of life for our citizens and elevate the reputation of USF Tampa through performances, works of art, published books and other writings, and public commentary. In support of the next generation of scholars, USF Tampa has established the Provost's Postdoctoral Scholars Initiative in Humanities and Social Sciences. This initiative supports five new postdoctoral scholars per year in these areas and has established a new Office of Postdoctoral Affairs in the Graduate School that facilitates strategic planning and data collection related to all USF postdoctoral scholars. Overall, there has been an increase in the number of postdoctoral scholars from 103 in 2003, to 261 postdoctorates reported for Fall 2009.

In 2008-09, three members of the USF Tampa faculty were identified as national academy members and eight received nationally prestigious faculty awards as defined by the Top American Research Universities (TARU). USF Tampa's commitment to applied research is evident by a 50\% increase in the total number of patents issued since 2004. 


\section{GOAL 4: MEETING COMMUNITY NEEDS AND FULFILLING UNIQUE INSTITUTIONAL RESPONSIBILITIES}

The core of the USF System is a growing, energetic campus in the heart of Tampa. What was once known as local university serving commuter students, today USF is one of the nation's top research universities with a vibrant campus community and strong research focus.

USF Tampa's 2007-2012 Strategic Plan is a bold, ambitious plan to elevate the performance and rankings of USF Tampa and provides the USF community with a clear vision, goals, strategies and measures to promote alignment and success. It is clearly directed at ensuring student success, contributing innovation and new knowledge and advancing economic development in Florida, the nation, and globally.

With a $213 \%$ increase in federal research enterprise between 2000-2007, no other American university grew its federal funding at a faster rate than USF, according to the Chronicle of Higher Education's 2009-10 Almanac. This distinction is a clear example of USF Tampa's aspirations to become eligible for membership in the Association of American Universities (AAU), an organization of 62 leading public and private research universities in the U.S. and Canada (34 public, 26 private, 2 Canadian). A focus on meeting the stringent criteria for AAU invitation-only membership represents the highest level in which a university can benchmark its achievements.

A unique example of the integration of the USF Tampa Strategic Plan into the university's operations is the way USF Tampa incorporates the budget planning process into the implementation of the strategic planning process. USF Tampa aligns its budget with institutional strategic priorities through effectively communicating and engaging all stakeholders in a transparent, focused, and disciplined manner with a mind to preserving excellence, containing costs, leveraging efficiencies, generating new revenue, and maximizing performance.

USF Tampa's focus on integrated, interdisciplinary inquiry, one of the four pillars of the university's strategic plan, is evident both in instructional and research programs. From new doctoral programs to undergraduate research, graduate school partnerships, and community outreach initiatives, USF is positioned as an emerging global leader in a new way of approaching learning and discovery.

USF Health is an enterprise dedicated to making life better by improving health in the wider environment, in communities, and for individuals. USF Health has, as its core, the three colleges of Public Health, Nursing and Medicine, including a School of Physical Therapy as well as the healthcare delivered by its clinicians. Originally founded as the USF Medical Center in 1965, its name has been changed to USF Health to reflect its collaborative focus on the full continuum of health.

Recently, the Florida Board of Governors granted USF Tampa approval to establish new doctoral programs in history, government, and sociology. The programs are linked, which is quite different from traditional, disciplinebased programs. They focus on building sustainable healthy communities in a global context. These new programs join existing dual and interdisciplinary degree programs both at the undergraduate and graduate level.

In recognition of USF Tampa's service in the community, it was placed on the Corporation for National and Community Service's President's Higher Education Community Service Honor Roll for exemplary service efforts and service to America's communities. 
Current Peer Institutions

Below are the national peer institutions as set forth in the USF Tampa Strategic Plan:

\section{National Peer Institutions}

- North Carolina State University

- Rutgers University

- University at Buffalo

- Stony Brook University

- University of Alabama at Birmingham

- University of California, Irvine

- University of Cincinnati

- University of Illinois at Chicago 


\section{Institutional Vision and Strategic Directions for the Next 5 - 10 Years}

\section{USF Tampa Visions:}

The University of South Florida Tampa envisions itself as a pre-eminent research university with state, national and global impact, and positioned for membership in the Association of American

Universities (AAU). http://www.ods.usf.edu/Plans/Strategic/vision-mission.htm

The strategic goals set forth by USF Tampa are designed to help meet the distinctive needs of region and the State of Florida by stimulating innovation in a knowledge-based economy aligned with New Florida initiatives. These goals include: expanding research and scholarly endeavors; promoting high quality learning environment; growing global initiatives; and enhancing revenue sources. The following outline the specific strategic directions for USF Tampa:

\section{Expanding world-class interdisciplinary research, creative, and scholarly endeavors.}

- Promote nationally and internationally distinctive and prominent research and graduate programs,

- Strengthen the University's research support infrastructure to enhance contracts and grants workflow and output - through critically examining the applicability of alternative models of F\&A indirect cost distribution, and other innovative mechanisms,

- Focus on increasing the amount and proportional share of competitive federal research awards,

- Enhance and expand the talent pool of world-class, competitively-funded faculty members, postdoctoral fellows, and graduate students,

- Establish a salary enhancement program that rewards highly productive faculty in the areas of teaching and learning; scholarship, research and creative endeavors; and service and engagement, and

- Strengthen and support integrated and synergistic interdisciplinary research across disciplinary, departmental, college and campus boundaries.

Promoting globally competitive undergraduate, graduate and professional programs that support interdisciplinary inquiry, intellectual development, knowledge and skill acquisition, and student success through a diverse, fully-engaged, learner-centered campus environment.

- Create and support globally competitive, relevant and distinctive academic programs that address the changing needs of the region, state and nation through innovative approaches to curriculum development and delivery,

- Provide increased access to excellence in higher education for students who demonstrate the aptitude to succeed,

- Enhance and expand the talent pool by shaping the enrollment profile of USF Tampa's undergraduate and graduate student body to reflect that found at a pre- eminent research university,

- Improve year-to-year retention and time-to-graduation; demonstrated acquisition of knowledge, communication and critical thinking skills; and competency to synthesize and apply new knowledge; together with providing an optimal college experience for all students, 
- Build a sustainable campus environment at USF Tampa that meets the criteria for Carnegie classification as a "primarily residential" campus, and

- Improve and promote cultural and global literacy, foreign language proficiency, and the international competitiveness of USF Tampa graduates through significant growth in study abroad participation, an increase in fee-paying international students, and cross-cultural curriculum development.

Expanding local and global engagement initiatives to strengthen and sustain healthy communities and to improve the quality of life.

- Establish a unified institutional structure to facilitate and promote community engagement, social enterprise, and global collaborations in education, research and service learning, including mechanisms for managing fiscal and human resources for student exchange, study abroad and international field placement programs, and faculty research, teaching, outreach and professional development opportunities,

- Develop an up-to-date clearinghouse of information about all the engagement currently occurring at USF Tampa and develop institutional systems to measure community engagement,

- Encourage and reward faculty effort in community engagement - require an annual faculty impact statement and explicitly introduce community engagement into USF Tampa's promotion and tenure guidelines, and

- Encourage and reward student engagement in the community and explore the feasibility of acknowledging community engagement and other co-curricular activities on the official transcript.

Enhancing all sources of revenue, and maximizing effectiveness in business practices and financial management to establish a strong and sustainable economic base in support of USF's growth.

- Refine business practices to ensure a strong and sustainable economic foundation at USF Tampa,

- Promote and sustain a positive working environment, significantly improve service quality, and improve staff support through providing competitive salary structures, expanding professional development opportunities, and building cross-functional teams,

- Build USF Tampa's fundraising enterprise and endowment to a level commensurate with that found at a pre-eminent research university by completing a comprehensive campaign to support capital projects, endowed professorships and scholarships, and to supplement operating needs,

- Expand USF Tampa's national identity through developing and implementing a comprehensive, cutting-edge branding campaign grounded in the discovery and dissemination of new knowledge; interdisciplinary collaboration; commercialization and economic development; and global engagement,

- Expand the commercialization of emerging technologies to enhance regional and state economic development, and

- Build a sustainable environment to support an expanded and improved teaching and research mission, a more engaged residential community, and a university-based global village.

USF Tampa Strategic Plan: http://www.ods.usf.edu/Plans/Strategic/ 
Aspirational Peer Institutions (aspire and plan to be comparable to in the next 5 - 10 years)

- Georgia Institute of Technology

- University of Pittsburgh

- University of California, San Diego 
University of South Florida-Tampa

SUS Work Plans 2010

\begin{tabular}{|c|c|c|c|c|c|c|}
\hline \multicolumn{7}{|c|}{ Projected Institutional Contributions to System-Level Goals } \\
\hline \multicolumn{7}{|c|}{ NUMERIC TARGETS } \\
\hline Dashboard Metric & Date & \multicolumn{2}{|c|}{ Actual Value } & Date & \multicolumn{2}{|c|}{ Projected Value } \\
\hline Baccalaureate Degrees Awarded & 2008-09 & \multicolumn{2}{|c|}{6,059} & $2012-13$ & \multicolumn{2}{|r|}{6,786} \\
\hline Master's Degrees Awarded & 2008-09 & \multicolumn{2}{|c|}{1,810} & $2012-13$ & \multicolumn{2}{|r|}{2,375} \\
\hline $\begin{array}{l}\text { Research and Professional Doctorates } \\
\text { Awarded }\end{array}$ & 2008-09 & \multicolumn{2}{|c|}{402} & 2012-13 & \multicolumn{2}{|r|}{488} \\
\hline $\begin{array}{l}\text { Federal Academic Research and } \\
\text { Development Expenditures }\end{array}$ & 2007-08 & \multicolumn{2}{|c|}{ SYSTEM ONLY } & 2011-12 & \multicolumn{2}{|c|}{ SYSTEM ONLY } \\
\hline $\begin{array}{l}\text { Total Academic Research and } \\
\text { Development Expenditure }\end{array}$ & 2007-08 & \multicolumn{2}{|c|}{ SYSTEM ONLY } & 2011-12 & \multicolumn{2}{|c|}{ SYSTEM ONLY } \\
\hline \multirow{2}{*}{$\begin{array}{l}\text { FTIC }^{* * *} \text { Six-Year Retention and Graduate } \\
\text { Rates from the Same IHE }\end{array}$} & \multirow{2}{*}{$\begin{array}{l}\text { 2003-09 } \\
\text { FTIC } \\
\text { Cohort }\end{array}$} & \multicolumn{2}{|c|}{$\begin{array}{l}\text { Graduated } \\
\quad 46.7 \%\end{array}$} & \multirow{2}{*}{$\begin{array}{c}\text { 2007-13 } \\
\text { FTIC } \\
\text { Cohort }\end{array}$} & \multicolumn{2}{|r|}{$\begin{array}{l}\text { Graduated } \\
49.5 \%\end{array}$} \\
\hline & & \multicolumn{2}{|c|}{$\begin{array}{c}\text { Still Enrolled } \\
10.6 \%\end{array}$} & & \multicolumn{2}{|c|}{$\begin{array}{c}\text { Still Enrolled } \\
11.5 \%\end{array}$} \\
\hline \multirow{2}{*}{$\begin{array}{l}\text { AA Transfer }{ }^{* * *} \text { Four-Year Retention and } \\
\text { Graduation Rates from the Same IHE }\end{array}$} & \multirow{2}{*}{$\begin{array}{l}\text { 2005-09 } \\
\text { AAT } \\
\text { Cohort }\end{array}$} & \multirow{2}{*}{\multicolumn{2}{|c|}{$\begin{array}{c}\text { Graduated } \\
60.8 \% \\
\text { Still Enrolled } \\
62.5 \%\end{array}$}} & \multirow{2}{*}{$\begin{array}{c}\text { 2009-13 } \\
\text { AAT } \\
\text { Cohort }\end{array}$} & \multicolumn{2}{|r|}{$\begin{array}{c}\text { Graduated } \\
12.8 \%\end{array}$} \\
\hline & & & & & \multicolumn{2}{|c|}{$\begin{array}{l}\text { Still Enrolled } \\
11.5 \%\end{array}$} \\
\hline \multicolumn{7}{|c|}{ DIRECTIONAL TARGETS [Indicate Direction: I=Increase, $M=$ Maintain, $\mathrm{D}=$ Decrease] } \\
\hline Dashboard Metric & Date & \multicolumn{2}{|c|}{ Actual Value } & Date & \multicolumn{2}{|c|}{ Projected Direction** } \\
\hline Baccalaureate Degrees Awarded to Black, & רחק & \# & $\%$ * & 201213 & \# & $\% *$ \\
\hline Non-Hispanics & $2008-09$ & 786 & $13.5 \%$ & $2012-13$ & $\mathbf{I}$ & I \\
\hline Baccalaureate Degrees Awarded to & 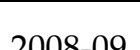 & \# & $\%$ * & 2012 13 & \# & $\%$ * \\
\hline Hispanics & $2000-09$ & 759 & $13.0 \%$ & $2012-10$ & $\mathbf{I}$ & $\mathbf{I}$ \\
\hline Baccalaureate Degrees Awarded to Pell & 2008_-09 & $\#$ & $\%$ * & $2012-13$ & \# & $\%^{*}$ \\
\hline Recipients & $2000-09$ & 2,260 & $38.8 \%$ & $2012-10$ & $\mathbf{M}$ & $\mathbf{M}$ \\
\hline Degrees Awarded in Specified STEM & בח & Bacc. & Grad. & 201213 & Bacc. & Grad. \\
\hline Fields & $2000-09$ & 1,323 & 528 & $2012-10$ & $\mathbf{I}$ & I \\
\hline Degrees Awarded in Specified Health & 2008 209 & Bacc. & Grad. & $2012-13$ & Bacc. & Grad. \\
\hline Profession Critical Need Areas & & 414 & 497 & & I & I \\
\hline Degrees Awarded in Specified Education & 2008-09 & Bacc. & Grad. & $2012-13$ & Bacc. & Grad. \\
\hline Critical Need Areas & & 86 & 126 & & $\mathbf{I}$ & I \\
\hline $\begin{array}{l}\text { NCLEX Pass Rate for First-Time Test } \\
\text { Takers in Baccalaureate Nursing Program }\end{array}$ & 2008 & & & 2012 & & $\mathbf{M}$ \\
\hline Licensing Income & 2007-08 & & & 2011-12 & & I \\
\hline Licenses and Options Executed & 2007-08 & & & 2011-12 & & I \\
\hline Other Transfer*** Five-Year Retention & 2004-09 & & & 2008-13 & & $\begin{array}{l}\text { Graduated } \\
\text { I }\end{array}$ \\
\hline and Graduation Rates from the Same IHE & Cohort & & & Cohort & & $\begin{array}{l}\text { Still Enrolled } \\
\text { I }\end{array}$ \\
\hline
\end{tabular}

"Actual Value" should equal related value in 2009 Annual Report.

* Percentage of Total Baccalaureates Awarded That Were Awarded to Specific Group.

** Projected Direction $=$ INCREASE, MAINTAIN, or DECREASE. 


\section{Additional Primary Institutional Goals/Metrics for the Next One to Three Years}

(In the context of the institutional strategic plan and vision, as well as System priorities, present a minimum of three additional goals on which university effort will be focused in the next one to three years. Describe each goal, including whether the goal is new or continuing, the strategy for achieving that goal, the metrics by which success will be measured, specific actions to be taken in this fiscal year, expected outcomes, and assumptions, including financial, upon which the projected outcomes are predicated.)

Moving Towards AAU Membership: Reflecting the institution's goals of becoming eligible for membership in the Association of American Universities, USF Tampa is dedicated to strengthening its excellence in teaching, research, and service by enhancing STEMM field activities, broadening its global connections, promoting interdisciplinary initiatives, and developing stronger community ties. The strategic plan documents in detail the metrics used to measure success, metrics for which the institution is held accountable by the Board of Trustees.

Revenue Enhancement -- Public-Private Partnerships: USF Tampa will continue its revenue enhancement initiatives through the development of external funding, private giving, technology transfer and public-private partnerships. USF Tampa will continue to sponsor research and creative scholarship activities to support external funding awards, patents issued, technology transfer and licensing revenues, and start-up companies formed. USF Tampa will champion endowment support and it will continue to foster partnerships with leading research and industry leaders, such Mote Marine Laboratory, SRI, New Energy Solar, NanoCVD, Florida Institute of Oceanography and Draper Laboratory. It will cultivate research and development that strengthens the state's economy while contributing to solutions for the world's most pressing challenges. USF Tampa will monitor the public-private partnerships for increases in external funding, patents and licenses.

Global Initiatives: In particular, it is anticipated that USF Tampa will see considerable increases in its global activities, international faculty exchanges, recruitment of fee-paying international students and student study abroad programs, thus adding to Florida's place in the global economy. USF Tampa is strategic in its use of resources as it moves in this direction. Its partnership with INTO will facilitate the internationalization of the campus. Additionally, in 2009, USF Tampa is working with Hobsons ICN to recruit degree program admissible undergraduate international students. USF Tampa will continue to monitor the number of international students on campus.

Technological Advances - Marine and Coastal Environments: An identified area of strategic focus, Marine Science and Coastal Technologies represents a key area of paralleled concentration of coastal marine programs. The Tampa Bay region is the largest marine research community in the southeast, and USF Tampa is uniquely positioned to serve as the intellectual hub for technological advances and workforce development within this important industry. USF Tampa will monitor research activities in coastal marine programs in terms of student recruitment, involvement, graduation, and placement, as well external research funding for these initiatives. 


\begin{tabular}{|c|c|c|c|c|}
\hline $\begin{array}{l}\text { Proposed Date of } \\
\text { Submission to } \\
\text { University Board } \\
\text { of Trustees }\end{array}$ & $\begin{array}{l}\text { Program } \\
\text { Level } \\
(\mathrm{B}, \mathrm{M}, \mathrm{D})\end{array}$ & $\begin{array}{l}\text { 6-Digit } \\
\text { CIP } \\
\text { Code }\end{array}$ & $\begin{array}{c}\text { Program Title or Degree } \\
\text { Designation }\end{array}$ & $\begin{array}{c}\text { Comments } \\
\text { (Including Proposed } \\
\text { Implementation Date) }\end{array}$ \\
\hline \multicolumn{5}{|c|}{ College of Arts and Sciences } \\
\hline TBD & $\mathrm{D}$ & 25.0101 & $\begin{array}{l}\text { Library and Information } \\
\text { Sciences }\end{array}$ & \\
\hline TBD & $\mathrm{D}$ & 26.0400 & Cell and Molecular Biology & \\
\hline TBD & $\mathrm{D}$ & 26.1399 & $\begin{array}{l}\text { Ecology, Evolution } \\
\text { Systematics and Population } \\
\text { Biology }\end{array}$ & \\
\hline TBD & M & 45.0701 & $\begin{array}{l}\text { Geographic Information } \\
\text { Systems }\end{array}$ & \\
\hline Fall 2010 & B & 51.0000 & Health Science & Spring 2011 \\
\hline \multicolumn{5}{|c|}{ College of Behavioral and Community Sciences } \\
\hline 2011-2012 & M & 30.1101 & $\begin{array}{l}\text { 5-Year Masters of } \\
\text { Gerontology }\end{array}$ & $\begin{array}{l}\text { Will provide opportunity } \\
\text { for outstanding } \\
\text { undergraduate Gerontology } \\
\text { students to complete the } \\
\text { MA with } 1 \text { additional year } \\
\text { of enrollment }\end{array}$ \\
\hline TBD & M & 51.0718 & $\begin{array}{l}\text { Long-Term Care } \\
\text { Administration }\end{array}$ & $\begin{array}{l}\text { Based on our BS in LTC } \\
\text { Administration, this } \\
\text { program would prepare } \\
\text { administrators who already } \\
\text { have a relevant bachelors } \\
\text { degree }\end{array}$ \\
\hline TBD & M & 52.0299 & $\begin{array}{l}\text { Management of Health and } \\
\text { Aging Programs }\end{array}$ & $\begin{array}{l}\text { Possibly offered as a joint } \\
\text { program with Public Health } \\
\text { and/or Business }\end{array}$ \\
\hline TBD & $\mathrm{D}$ & $x x . x x x x$ & $\begin{array}{l}\text { Ph.D. in Applied Behavior } \\
\text { Analysis }\end{array}$ & $\begin{array}{l}\text { Pre-proposal to GECC fall } \\
2009\end{array}$ \\
\hline \multicolumn{5}{|c|}{ College of Education } \\
\hline TBD & M & 13.0901 & Educational Studies & Pre-proposal 3/10 \\
\hline TBD & M & 31.0505 & Exercise Science & Pre-proposal 4/10 \\
\hline $2010-2011$ & M & $x x . x x x x$ & $\begin{array}{l}\text { MA in Autism Spectrum } \\
\text { Disorders and Severe } \\
\text { Intellectual Disabilities }\end{array}$ & $\begin{array}{l}\text { Pre-proposal to GECC } \\
4 / 2010\end{array}$ \\
\hline
\end{tabular}




\begin{tabular}{|c|c|c|c|c|}
\hline \multicolumn{5}{|c|}{ College of Medicine } \\
\hline 2012 & M & 5.2099 & Pharmaceutical Sciences & 2012 \\
\hline 2012 & M & 23.1303 & $\begin{array}{l}\text { Biomedical Communication \& } \\
\text { Marketing }\end{array}$ & 2012 \\
\hline 2012 & $\mathrm{D}$ & 26.0608 & Integrated Neurosciences & 2013 \\
\hline 2011 & $\mathrm{M}$ & 26.0907 & $\begin{array}{l}\text { Diabetes \& Autoimmune } \\
\text { Diseases }\end{array}$ & 2011 \\
\hline 2011 & $\mathrm{M}$ & 30.2401 & Behavioral Neurosciences & 2011 \\
\hline 2012 & $\mathrm{M}$ & 51.0701 & Healthcare Management & 2013 \\
\hline 2012 & M & 51.0912 & Physician's Assistant & 2012 \\
\hline 2011 & M & 51.2706 & Health Informatics & 2011 \\
\hline 2012 & $\mathrm{M}$ & 51.3102 & Clinical Nutrition & 2012 \\
\hline 2013 & $\mathrm{D}$ & 51.9999 & Infectious Diseases & 2013 \\
\hline 2011 & $\mathrm{D}$ & $X X . X X X X$ & $\begin{array}{l}\text { Rehabilitation Sciences } \\
\text { (Interdisciplinary) }\end{array}$ & 2012 \\
\hline \multicolumn{5}{|c|}{ College of The Arts } \\
\hline 2013 & $\mathrm{D}$ & 50.0703 & Art History & \\
\hline 2011 & $\mathrm{M}$ & 50.0704 & Arts Management & $\begin{array}{l}\text { Interdisciplinary with The } \\
\text { College of Business }\end{array}$ \\
\hline 2013 & M & $X X . X X X X$ & Museum Studies & \\
\hline
\end{tabular}

* Under review by the BOG June 2010 


\section{Windows of Opportunity/Unique Challenges}

(If the university has been presented with one or more unique opportunities that have not been included in prior plans but which will receive particular attention during this year, those opportunities should be presented here.

Additionally, if the university expects to face a unique challenge in the coming year(s), that should be noted.)

\section{Opportunities: Global Expansion}

○ INTO USF: The USF Tampa and INTO University Partnerships embarked on a joint venture to increase international student recruitment at USF Tampa and ensure greater student success. The new INTO>>USF international study center, based at USF's Tampa campus, will offer a unique range of programs that will help USF capitalize on the growing number of international students seeking to study in the USA. The innovative year-long preparation courses provide international students with the specific academic, English and cultural skills needed for successful study in American universities. In time, the study center intends to broaden its course portfolio to support USF Tampa's long term goals to provide more globally competitive undergraduate, graduate and professional programs; enhance global literacy; and expand global engagement initiatives.

- School of Global Sustainability: USF Tampa launched one of the nation's first Schools of Global Sustainability in February 2010, an innovative effort aimed at preparing students for a new generation of "green collar" careers and finding solutions for a world challenged with the protection of its fragile environment and limited resources. The first degree program to be offered by the school will be a Master of Arts (MA) in Global Sustainability to prepare students to address complex regional, national, and global challenges related to sustainability and the ability to innovate in diverse cultural, geographic, and demographic contexts. The program will allow for the integration of various disciplines such as basic, natural, and social sciences, engineering, health, economics, governance and policy, and issues of diversity.

- Global Academic Partners (GAP) Program: The purpose of the Global Academic Partners (GAP) Program is to provide an opportunity to develop meaningful and mutually beneficial collaborative research, teaching, and creative activities between USF and our Global Academic Partner Universities. Current partner universities are: Nankai University in China, Ocean University also in China, University of Exeter in the United Kingdom, University of Ghana in Ghana, and University of the Cape Coast, also in Ghana.

- USF Tampa's Role in the Emerging USF System: USF Tampa serves as the core institution to the USF System but works collaboratively with the other three institutions to provide distinction in teaching, research and service.

USF Tampa is a leading metropolitan research university, dedicated to excellence in:

- Student access and success in an engaged, and interdisciplinary, learner-centered environment,

- Research and scientific discovery, including the generation, dissemination, and translation of new knowledge across disciplines; to strengthen the economy; to promote civic culture and the arts; and to design and build sustainable, healthy communities, and

- Embracing innovation, and supporting scholarly and artistic engagement to build a community of learners together with significant and sustainable university-community partnerships and collaborations. 
Tuition Differential Proposal for 2010-2011

University: University of South Florida-Tampa

Effective Date

\begin{tabular}{|l|l|}
\hline University Board of Trustees Approval Date: & June $16^{\text {th }} 2010$ \\
\hline Implementation Date (month/year): & August 2010
\end{tabular}

\section{Purpose}

Describe the overall purpose of the tuition differential at this institution and the aspects of undergraduate education the funds are intended to improve.
1. Increase undergraduate course offerings

2. Improve graduation rates

3. Increase the percentage of undergraduate students who are taught by faculty

4. Decrease student-faculty ratios

5. Improve the efficiency of the delivery of undergraduate education through academics who graduate with excess hours

\section{Campus or Center Location}

Campus or Center Location to which the Tuition

Differential fee will apply. (If the entire university, indicate as such.)
The entire University of South Florida System (Tampa, St. Petersburg, Sarasota-Manatee, and Polytechnic)

\section{Undergraduate Course(s)}

Course(s). (If the tuition differential fee applies to all university undergraduate courses, indicate as such. If not, also provide a rationale for the differentiation among courses.)

\section{Tuition differential will apply to all}

undergraduate courses offered by the USF system

\section{Current Base Tuition and Tuition Differential Fee}

Current (2010-11) Undergraduate Base Tuition per credit hour:

$\$ 95.67$

Current Undergraduate Tuition Differential per

credit hour:

$\$ 22.00$

\section{Proposed Increase in the Tuition Differential Fee}

Percentage tuition differential fee increase (calculated

as a percentage of the sum of base tuition plus tuition differential):

$\$$ Increase in tuition differential per credit hour:

\$ Increase in tuition differential for 30 credit hours:

$7 \%$

$\$ 8.26$

$\$ 247.80$ 


\section{Projected Differential Revenue Generated and Intended Uses}

Incremental differential fee revenue generated

in 2010-11 (projected):

Total differential fee revenue generated in

2010-11 (projected): $\$ 5,292,991$

(Tampa-\$4,951,995; Health-\$340,996)

$\$ 13,764,091$

(Tampa-\$12,898,529; Health-\$865,562)

Seventy percent $(70 \%)$ of the total differential revenue generated must be used for undergraduate education. The total estimated amount to be spent on undergraduate education is $\$ 9,634,864$.

Describe in detail the initiative(s) and the estimated expenditure(s) for each:

1. Increase course offerings $(\$ 884,480)$

2. Improve graduation rates $(\$ 686,966)$

3. Increase the percentage of undergraduate students who are taught by faculty $(\$ 3,481,076)$

4. Decrease student-faculty ratios $(\$ 3,900,193)$

5. Improve the efficiency of the delivery of undergraduate education through academic advisement and counseling $(\$ 682,148)$

Thirty percent $(30 \%)$ of the total differential revenue generated must be used for undergraduate students who have financial need. Total estimated amount to be spent on financial need is $\$ 4,129,227$. If private sources are to be used, then the estimated amount of private dollars to be raised to offset the fee revenue is $\$ 0$.

Describe in detail the initiative(s) and the estimated expenditure(s) for each:

1. We will continue to target our need based grant awards to students who are paying the differential charges. Total expenditures: \$3,096,920

2. Because we continue to experience an increase in FAFSA filers who have need, the differential revenue will prevent dilution of the need based funds that are being awarded to an increasing number of students. Total expenditures: $\$ 1,032,307$

\section{Monitoring}

Indicate how the university will monitor the success of the tuition differential fee. Provide specific performance metrics that will be used. Also, point out any metrics that are different from the prior year and any prior year metrics that are no longer listed.
1. Freshman retention rate.

2. Six-year graduation rate for FTICs.

3. Three-year graduation rate for transfer students with AA degree.

4. Student to advisor ratio.

5. Student to faculty ratio. 
Performance Measure Status

What is the institution's plan for improving performance on the identified measure(s)? Show initial/baseline data starting with the year before each metric was identified, the goal for each metric, time frame for achieving the goal, and where the institution is now in relation to the goal if not in the initial year.
The USF Tampa strategic plan documents in detail the metrics used to measure success, metrics for which the institution is held accountable by the Board of Trustees. 1. Freshman retention rate: (2007-08) $81 \%$; goal of $90 \%(2011-12)$

2. Six-year graduation rate: $49.3 \%$ (Fall 2001 cohort); goal of $63 \%$ (Fall 2005 cohort)

3 . Three-year graduation rate for transfer students with AA degrees: 48\% (2003 cohort); goal of $55 \%$ (2007 cohort)

4. Student to advisor ratio: (2007-08) 480:1; goal 300/350:1

5. Student to faculty ratio: current- 27.5:1; goal to reduce this ratio to the national average 


\section{Tuition Differential Supplemental Information}

Provide the following information for the 2009-2010 academic year.

\section{9-2010 - 70\% Initiatives (List the}

initiatives provided in the 2009-10 tuition differential request.)

USF Tampa:

a. Increase course offerings

b. Improve graduation rates

c. Increase the percentage of undergraduate

students who are taught by faculty

d. Decrease student-faculty ratios

e. Improve the efficiency of the delivery of undergraduate education through academic advisement and counseling

\section{USF Health:}

a. Increase the percentage of undergraduate students who are taught by faculty

\section{University Update on Each Initiative}

The $70 \%$ collected to be used to enhance undergraduate education was allocated to hiring new professors, instructors, and academic advisors.
USF Health offers only two undergraduate programs: one in the College of Nursing and one in the College of Medicine. Differential revenue is being used in support of reducing the student/faculty ratio in clinical experiences. Both full-time faculty and adjunct instructors are currently supported. The College of Public Health (COPH) does not have undergraduate programs. However, COPH offers undergraduate classes that are part of the minor in public health and other general service courses for the university. Revenue from these classes is being used to support the salary of adjunct instructors. These funds have allowed USF Health to support the existing level of undergraduate adjunct instructors and therefore maintain/increase the number of undergraduate course offerings at a time of continued base budget reductions. The total expenditure includes some carry forward funds and thus exceeds the tuition differential revenue.

\section{Additional Detail, where applicable}

Number of Faculty Hired or Retained (funded by tuition differential):

Number of Advisors Hired or Retained (funded by tuition differential):

Number of Course Sections Added or Saved (funded by tuition differential):
Tampa: 22 (11 assistant professors, 11 instructors) Health: 8 (2 assistant professors, 6 instructors), 1 student assistant 
2009-2010 - 30\% Initiatives (List the initiatives provided in the 2009-10 tuition differential request.)

\section{University Update on Each Initiative}

A portion of the $30 \%$ of the differential fee revenue (approx. $\$ 200,000$ ) will be held for USF to provide grant funding for students whose families experience changes in their financial situation.

The remaining amount would be awarded to The differential funding increase resulted in funding eligible continuing students (as defined above) in an effort to address some of the unmet for 577 additional students, or an increase of almost sixteen percent. need.

Only $\$ 4,000$ has been used from this fund as of this date.

\section{Additional Information (estimates as of April 30, 2010)}

Unduplicated Count of Students Receiving at least one Tuition Differential-Funded 2,171

Award:

\$ Mean (per student receiving an award) of Tuition Differential-Funded Awards:

\$ Minimum (per student receiving an award) of Tuition Differential-Funded Awards:

\$ Maximum (per student receiving an award) of Tuition Differential-Funded Awards: 


\section{STATE UNIVERSITY SYSTEM OF FLORIDA}

Tuition Differential Collections, Expenditures, and Available Balances

University: University of South Florida - Tampa (includes Health)

Fiscal Year 2009-2010 and 2010-11

\section{University Tuition Differential}

Budget Entity: 48900100 (Educational \& General)

SF/Fund: 2 164xxx (Student and Other Fees Trust Fund)

\section{Estimated Actual* \\ 2009-10}

\section{Balance Forward from Prior Periods}

Balance Forward

$\begin{array}{r}\$ 87,769 \\ 0 \\ \hline \$ 87,769\end{array}$

Beginning Balance Available:

\section{Receipts/Revenues}

Tuition Differential Collections

Interest Revenue - Current Year

Interest Revenue - From Carryforward Balance

Total Receipts / Revenues:

\section{Expenditures}

$\$ 6,931,107$

$\$ 6,945,958$

\section{Estimated}

2010-11
Salaries \& Benefits

Other Personal Services

Expenses

Operating Capital Outlay

Student Financial Assistance

Expended From Carryforward Balance

${ }^{* *}$ Other Category Expenditures

Total Expenditures:

Ending Balance Available:

*Since the 2009-10 year has not been completed, provide an estimated actual.

$\$ 4,631,910$

66,463

\section{0}

0

$2,079,333$

$4,138,100$

**Provide details for "Other Categories" used.

${ }^{* * *}$ Estimated 2010-11 expenditures are rough estimates at this time. Budgets are currently being developed and will not be finalized until Summer 2010 
University of South Florida - Tampa

SUS Work Plans 2010

Enrollment Plan Proposal (May need to be submitted later than the rest of the Work Plan)

USF Tampa

\begin{tabular}{|c|c|c|c|c|c|c|c|c|}
\hline $\begin{array}{l}\text { For entire } \\
\text { institution }\end{array}$ & Funded & Estimated & Funded & Estimated & Estimated & Estimated & Estimated & $\begin{array}{c}\text { 5-Year } \\
\text { Projected }\end{array}$ \\
\hline FTE & 2009-10 & 2009-10 & $2010-11$ & 2010-11 & 2011-12 & 2013-14 & 2015-16 & $\begin{array}{c}\text { Annual } \\
\text { Growth } \\
\text { Rate }\end{array}$ \\
\hline $\begin{array}{l}\text { FL Resident } \\
\text { Lower }\end{array}$ & 8,617 & 7,928 & 8,617 & 8,088 & 8,040 & 8,000 & 8,000 & $-0.2 \%$ \\
\hline $\begin{array}{l}\text { FL Resident } \\
\text { Upper }\end{array}$ & 9,999 & 10,190 & 9,999 & 10,536 & 10,853 & 11,430 & 11,833 & $2.5 \%$ \\
\hline $\begin{array}{l}\text { FL Resident } \\
\text { Grad I }\end{array}$ & 2,672 & 2,554 & 2,672 & 2,605 & 2,657 & 2,765 & 2,876 & $2.1 \%$ \\
\hline $\begin{array}{l}\text { FL Resident } \\
\text { Grad II }\end{array}$ & 623 & 716 & 623 & 752 & 797 & 921 & 1,104 & $9.4 \%$ \\
\hline $\begin{array}{l}\text { Total FL } \\
\text { Resident }\end{array}$ & 21,911 & 21,389 & 21,911 & 21,981 & 22,347 & 23,115 & 23,814 & $1.7 \%$ \\
\hline & & & & & & & & \\
\hline $\begin{array}{l}\text { Non-res } \\
\text { Lower }\end{array}$ & & 306 & & 321 & 337 & 372 & 410 & $5.5 \%$ \\
\hline $\begin{array}{l}\text { Non-res } \\
\text { Upper }\end{array}$ & & 326 & & 342 & 359 & 396 & 437 & $5.6 \%$ \\
\hline $\begin{array}{l}\text { Non-res } \\
\text { Grad I }\end{array}$ & & 350 & & 378 & 408 & 476 & 555 & $9.4 \%$ \\
\hline $\begin{array}{l}\text { Non-res } \\
\text { Grad II }\end{array}$ & & 236 & & 250 & 268 & 315 & 385 & $10.8 \%$ \\
\hline $\begin{array}{l}\text { Total Non- } \\
\text { res }\end{array}$ & & 1,218 & & 1,292 & 1,373 & 1,559 & 1,787 & $7.7 \%$ \\
\hline & & & & & & & & \\
\hline Total Lower & 8,617 & 8,234 & 8,617 & 8,409 & 8,377 & 8,372 & 8,410 & $0.0 \%$ \\
\hline Total Upper & 9,999 & 10,516 & 9,999 & 10,878 & 11,212 & 11,826 & 12,270 & $2.6 \%$ \\
\hline Total Grad I & 2,672 & 2,904 & 2,672 & 2,983 & 3,065 & 3,241 & 3,431 & $3.0 \%$ \\
\hline Total Grad II & 623 & 952 & 623 & 1,002 & 1,065 & 1,236 & 1,489 & $9.7 \%$ \\
\hline Total FTE & 21,911 & 22,607 & 21,911 & 23,273 & 23,720 & 24,674 & 25,601 & $2.0 \%$ \\
\hline
\end{tabular}


For each distinct location (main, branch, site, regional campus) that has or is planned to have more than 150 FTE

\begin{tabular}{|c|c|c|c|c|c|c|c|c|}
\hline \multicolumn{9}{|l|}{ SITE: Tampa } \\
\hline For entire & Funded & Estimated & Funded & Estimated & Estimated & Estimated & Estimated & \multirow{2}{*}{$\begin{array}{c}\text { 5-Year } \\
\text { Projected } \\
\text { Average } \\
\text { Annual } \\
\text { Growth Rate }\end{array}$} \\
\hline FTE & 2009-10 & 2009-10 & $2010-11$ & 2010-11 & 2011-12 & 2013-14 & 2015-16 & \\
\hline Total Lower & 8,617 & 8,234 & 8,617 & 8,409 & 8,377 & 8,372 & 8,410 & $0.0 \%$ \\
\hline Total Upper & 9,999 & 10,516 & 9,999 & 10,878 & 11,212 & 11,826 & 12,270 & $2.6 \%$ \\
\hline Total Grad I & 2,672 & 2,904 & 2,672 & 2,983 & 3,065 & 3,241 & 3,431 & $3.0 \%$ \\
\hline Total Grad II & 623 & 952 & 623 & 1,002 & 1,065 & 1,236 & 1,489 & $9.7 \%$ \\
\hline Total FTE & 21,911 & 22,607 & 21,911 & 23,273 & 23,720 & 24,674 & 25,601 & $2.0 \%$ \\
\hline \multicolumn{9}{|l|}{ SITE: Health } \\
\hline $\begin{array}{l}\text { For entire } \\
\text { institution }\end{array}$ & Funded & Estimated & Funded & Estimated & Estimated & Estimated & Estimated & \multirow{2}{*}{$\begin{array}{c}\text { 5-Year } \\
\text { Projected } \\
\text { Average } \\
\text { Annual } \\
\text { Growth Rate }\end{array}$} \\
\hline FTE & 2009-10 & 2009-10 & $2010-11$ & 2010-11 & 2011-12 & 2013-14 & 2015-16 & \\
\hline Total Lower & 104 & 349 & 104 & 319 & 325 & 329 & 333 & $0.9 \%$ \\
\hline Total Upper & 584 & 875 & 584 & 854 & 897 & 919 & 952 & $2.3 \%$ \\
\hline Total Grad I & 498 & 1,044 & 498 & 985 & 1,038 & 1,220 & 1,377 & $8.0 \%$ \\
\hline Total Grad II & 229 & 198 & 229 & 220 & 224 & 226 & 226 & $0.5 \%$ \\
\hline Total FTE & 1,414 & 2,467 & 1,414 & 2,378 & 2,484 & 2,694 & 2,888 & $4.3 \%$ \\
\hline
\end{tabular}

